\title{
A Narrative Stylistic Approach to Narrative Shift in Prophet Ayyub's Qur'anic Story
}

\author{
Submitted by \\ Dina Ragab Muhammad Gassor \\ PhD Student
}

\begin{abstract}
The present study is intended as a guide for all Qur' an readers and listeners to show interest in understanding and studying the text of The Holy Quran. Arabic has always stood between researchers/readers/listeners and their full comprehension, their tools and their final product, due to its heavy grammar and formidably polysemous vocabulary.
\end{abstract}

Studies and research on Narrativity and Cognitive Stylistics have attracted the attention of many researchers in the field of the Qur'anic discourse. Most researches deal with the discourse of the Qur'an from either a stylistic view or a narrative one. However, no research has dealt with both, the cognitive stylistic view and the narrative view all together. The discourse of the Qur'an has its own structural nature since its grammar, lexicons and sounds are all specific to it. However, the purpose of each part of its discourse allows for certain interpretations and meanings. So, a special theoretical framework is used here to reflect the uniqueness of the Qur'an as a miraculous text book.

The present study examines the Qur'anic discourse by analyzing its prophetic stories. The study aims at identifying the Qur'anic narrative shift occurring in the Qur'anic discourse along with its form and function. It also aims at identifying the reasons why the Narrative Shift allows for the Qur'anic intertextuality by tracing the 
frequency of its occurrence inside the Qur'an. The study also investigates the relation between the Narrativity style of the Qur'an and its effectiveness and persuasiveness to its readers and listeners. It also examines the general and specific functions behind using the shift in the narrative progression.

\section{Keywords:}

Narrativity, Cognitive Stylistics, Qur'anic Discourse, Intertextuality, Persuasion

\section{Introduction}

The present study is meant to shed the light on the Qur'anic Narrative Shifts. The researcher uses the term Shift referring to the alternation in narrating the same Qur'anic story. It examines the Quranic narratives from a lexico-grammatical stylistic perspective. Its primary goal is to reveal how far the analysis of Quranic narratives may help in the recognition of the specific features of its text's style and meaning. An extensive discussion of the Qur'anic narratives serves as a background to the discussion of the relation between the lexico-grammatical strategies and the intertextuality of the Qur'anic text. The study also argues that the Qur'anic rhetoric and persuasion crucially relies on the lexico-grammatical features of its narrative. Finally and mainly, the study explains all these functions and relations by applying specific stylistic narrative theories on all the narrative shifts of prophets' Qur'anic stories.

\subsection{Context of the study}

The Qur'anic narrative is the main ground on which the study of Islamic religion has grown and still rests. Moreover, the flourishing of linguistics and disciplines 
studying religious texts, language, and narrative makes investigating Qur'anic narrative linguistic features part of our thinking, recollecting, imagining, explaining, and understanding the Qur'anic language.

The present study applies a lexico-grammatical analysis to understand the style of the Qur'anic narratives and analyze their linguistic features that lead the researcher to justify the significance of structuring the narratives in the way they are and should lead to better understanding of the Qur'anic narrative discourse.

\subsection{Objectives of the Study}

The present study is an attempt to analyze Qur'anic Narrative Shifts applying Paul Simpson's Narrative Stylistics Model (2004) to:

1. Explain the Qur'anic narrative style

2. Highlight the narrative shifts in the Qur'an's narrative

3. Understand the Qur'an phenomenal linguistic miraculousness by showing the Qur'an's rhetoric, persuasiveness, and intertextuality

\subsection{Research Questions}

This research attempts to investigate one major question and two subsidiary ones:

1. What are the Narrative Shifts, their linguistic characteristics, and their function in the Qur'an?

a. How are the Qur'anic rhetoric and persuasive devices expressed on the lexico-grammatical level?

b. To what extent have the Narrative Shifts influenced the Qur'anic discourse's intertextuality? 


\subsection{Significance of the Study}

The Qur'an has such a great value; it has presented itself as an important source of many branches of diverse sciences over ages. One of the most important aspects of it is its language. This study is meant to shed light on the Qur'anic interpretation in the light of its Narrative linguistic rhetoric. This study is an attempt to investigate the Qur'anic Narrative linguistic features and style. Due to the multifaceted features of the Qur'an, the study of its language and style is essential.

\section{Literature Review}

This section reviews the literature of the studies that dealt with Qur'anic narratives and narrative shifts. It also reviews the literature of the previous studies that applied Simpson's Model to Narratives.

\subsection{Qur'anic Narrative}

The classical exegetes' approaches were associated with studying the Qur'ānic narratives literal text. Theoretically, they assumed that the Qur'ān's literal meaning was prior to any exegesis and thus, represented a process rather than a result. They concluded that the Qur'anic narrative serves as a source of history and theology by recounting the historical and theological facts and situations that brought about that particular situation. In short, they assumed that the main purpose of these Qur'ānic narratives was to preserve the history of previous prophets nations and their theological mission. (Troudi, 2011)

Sufi exegetes have maintained that the metaphorical and allegorical interpretation of the Qur'ān is the fundamental source of self-seeking knowledge. They insisted on discovering its deeper meanings to justify the Sufi worldview and find their ideas in these texts within an Islamic framework. These philosophical and mystical 
approaches allowed them to allegorize the Qur'anic narrative text and find its esoteric meanings that lie behind the literal ones. Therefore, for Sufis, these stories have become the central theme that reflects the general culture of early classical Sufi Islam. For instance, Sufi commentators considered that all Qur'anic narratives are humanly accessible and divinely mysterious. Their hermeneutical efforts differed from the traditional and rational tafsīrs because they applied their mystical and allegorical visions to the Qur'anic narrative texts.

For the Literary approach, it emphasized that the stories of the Qur'an are allegories, amthal, not intended to convey historical fact. The body of such stories may appear historical, but their message does not necessarily reflect history. Their claim's evidence is that Qura'n deliberately does not mention either time or location of historical incidents in its stories, and it also omits some characters. Also, in dealing with several historical stories the Qur'an selects some events and leaves out others and it changes chronological order of events. It occasionally switches the characters performing given actions. When the story is repeated in another chapter of the Qur'an, a character's dialogue may be different from that of the spoken one in a previous context. And it occasionally and chronologically adds later incidents to the narrative.

\subsection{Narrative Perspectives to Religious Studies}

It is important to mention at the outset that most of the Qur'anic scholars and exegetes, classical as well as modern, have provided glossaries, commentaries, and discussions on the function and use of narratives in the Qur'an. For example, Badr al-Din al-Zarkashi (1391) in al-Burhann fi 'Ulum al-Qur'an and Jalal al-Din alSuyuti (1505)) in al-Itqann fi 'Ulum al- Qur'an have allocated separate sections on the discussion of narratives in the Qur'an (amthal al-Qur'an) with reference to 
Arabic rhetoric and the special significance of the Qur'an. In the same way, modern Qur'anic commentators like Amin Ahsan Islahi (1997) and Sayyid Qutb (1966) provide a detailed account of the use of narratives in their commentaries on the Qur'an. In addition, Abdul-Raof devotes a section of his "Exploring the Qur'an" to the Qur'anic narratives.

Scholars such as M. A. S. Abdel-Haleem; Issa J. Boullata; Mustansir Mir; Angelika Neuwirth; Andrew Rippin; John Wansbrough and Stefan Wild have conducted different studies on Qur'anic narratives. However, a specialised, rigorous and objective approach still resides in an embryonic and impressionistic state. This is due to the Qur'anic narrative linguistic nature that sometimes takes a non-narrative form.

Kermode (1979) discusses a number of significant points about the narrative nature of biblical narratives with reference to the New Testament, which could be applied to Qur'anic narratives as well. For example, he states that narratives reflect a range of senses which can be understood on a scale "at the one end of which is a zero point, a strong saying," without narrative content, and "at the other is the well-formed story" exhibiting "all the marks of narrativity." Some narratives are entirely transparent (that is, their meaning is clear) while others are very obscure and they mean different things to different people "mean more than they seem to say and they mean different things to different people, with a particularly sharp distinction drawn between those who are outside and those who are inside." (Kermode, p. 44)

Other scholars express similar ideas about biblical narratives though they do not seem to agree upon one single definition or explanation. Afsar (2005) conducts a basic survey of literature on narratives showing that there are certain characteristics shared by all parables, sacred or profane, in a range of different combinations. First, 
in a parable, there is usually a comparison between two apparently dissimilar things, objects, situations or persons. Secondly, a connecting word showing explicit comparison is used. For instance, words like "like" or "as" in English or their equivalents in other languages — hence "similitude" — are normally used. Thirdly, the objects of comparison are chosen from common, every-day life: such things as clouds, storm, lightning, thunder, gnat, fly, seed, tree, etc. Fourthly, there is usually a short narrative embedded, sometimes in an embryonic form, which is not meant to be taken only at face value. Fifthly, there is usually an aporia or gap in a parable which makes it susceptible to multiple and divergent interpretations. And finally, a parable is used for didactic purposes.

Kermode (1979) states that biblical narrative have a didactic purpose and they have double meanings, that is, one meaning for those who are "inside" - the believers, and the other for those who are "outside" - the unbelievers.

Asfar (2005) agrees with Kermode's view of biblical narratives and explains that in addition to incorporating the general characteristics of narratives, the Qur'an seems to indicate deliberate intent about its use of them. It not only defends their use but also makes sure that they are not misunderstood or underestimated by readers. $\mathrm{He}$ adds that Qur'anic narratives are considered a good vehicle for teaching moral lessons of usually sublime and abstract nature in ordinary and concrete terms.

In the present study, the researcher deals with both Qur'anic narratives that have explicit narrative content as well as those that have strong implicit narrative elements. 


\section{Methodology}

This Section deals with sources of data, how data is selected for the study, and the procedures of data analysis. Moreover, it provides the research methods adopted and the reasons behind choosing them.

\subsection{Theoretical Background}

In the present study, the researcher employs a lexico-grammatical analysis following a miscellaneous approach by adopting a very significant cognitive stylistic model theory:

- Paul Simpson's Model of Narrative Structure (2004)

\subsubsection{Lexico-grammar}

It is a term peculiar to systemic functional linguistics. It was coined by Michael Halliday, the father of systemic functional linguistics, to describe the continuity between grammar and lexis. For many linguists, these phenomena are discrete. But Halliday brings them together with this term. As with other dimensions of Halliday's theory, he describes the relation between grammar and lexis as one of a 'cline', and therefore, one of 'delicacy'. In 1961, he wrote "The grammarian's dream is...to turn the whole of linguistic form into grammar, hoping to show that lexis can be defined as "the most delicate grammar"". (Halliday, 1961, p.267)

The researcher believes that lexico-grammatical analysis gives a full insight into how the narrative message is encoded via the medium of language, on the one hand, and how it is organized to achieve this, on the other. Also, it is a core guide in the process of reading and interpreting the narrative rhetoric. 


\subsubsection{Narrative Structure Model}

Narrative discourse is the process of formal recollection and description of a series of activities for the purposes of ideology. For Simpson (2004), narrative discourse provides a way of recapitulating felt experience by matching up patterns of language to a connected series of events. According to him:

In its most minimal form, a narrative comprises two clauses which are temporally ordered, such that a change in their order will result in a change in the way we interpret the assumed chronology of the narrative events (p.18).

More fundamentally, however, this indicates that narratives require development, elaboration, and embellishment. They also need sufficient degrees of stylistic flourish to bestow on them the imprint of individuality or personality, for, as Simpson argues, stories narrated without that flourish will often be flat and dull. Although the task of providing an acceptable and rigorous model of narrative discourse has proved somewhat challenging for discourse stylisticians, there has been little disagreement on the procedure for isolating the various components of, say, a novel or a short story as well as the interconnectivity between these components.

Simpson, for instance, makes a primary distinction between two basic components of narrative - narrative plot and narrative discourse as follows:

The term plot is generally understood to refer to the abstract storyline of a narrative; that is, to the sequence of elemental, chronologically ordered events which create the 'inner core' of a narrative. Narrative discourse, by contrast, encompasses the manner or means by which that plot is narrated. Narrative discourse, for example, is often characterized by the use of stylistic devices such as flashback, prevision, and repetition - all of which serve to disrupt the basic chronology of the narrative's plot. Thus, narrative discourse represents the 
realised text, the palpable piece of language which is produced by a story-teller in a given interactive context.

(Simpson, 2004, p.20)

As identified by Simpson (2004) there are six basic stylistic units of analysis in narrative description as follows:

- Textual medium

- Sociolinguistic code

- Characterization 1: actions and events

- Characterization 2: points of view

- Textual structure

- Intertextuality

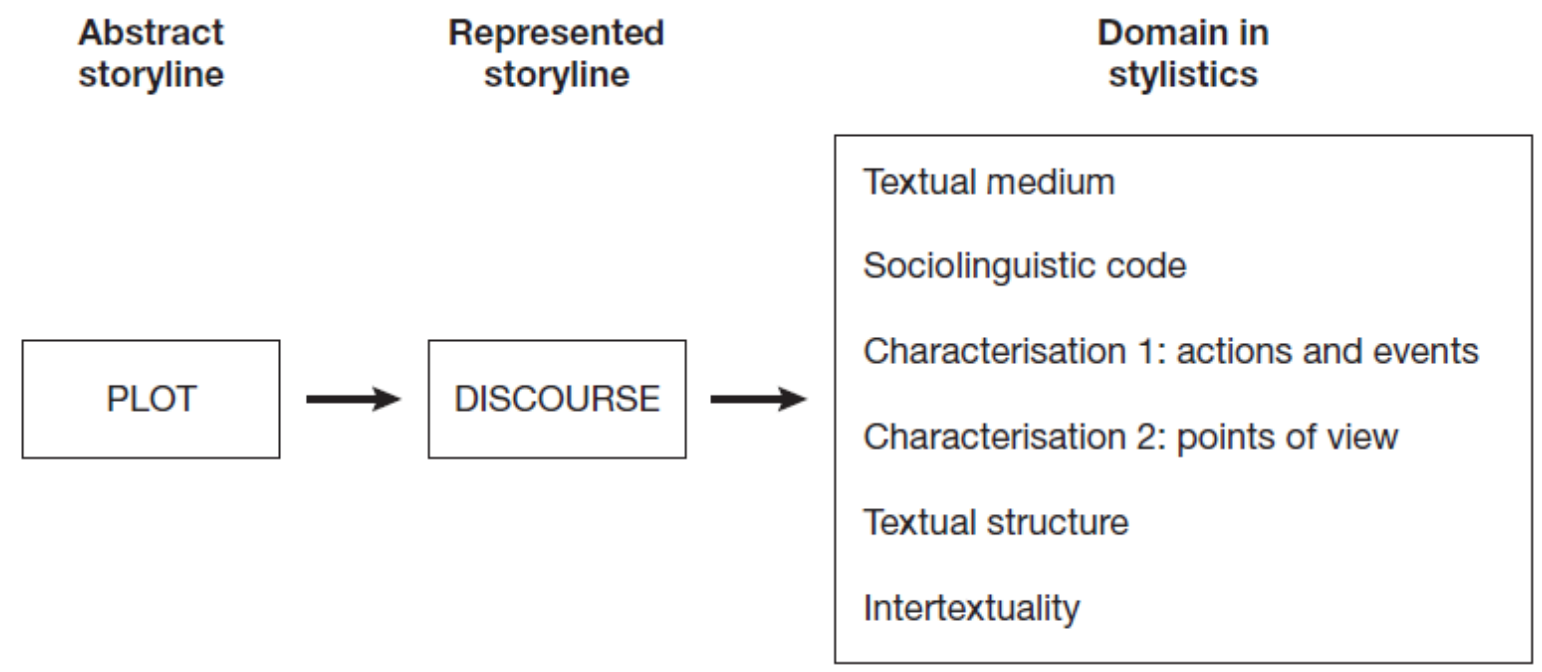

Figure 1: A model of narrative structure Adopted from Simpson, 2004, p. 20.

Much of our everyday experience is shaped and defined by actions and events, thoughts and perceptions and is an important function of the system of language that it is able to account for these various goings-on in the world. This means encoding into the grammar of the clause a mechanism for capturing what we say, think and 
do. More so it means that one looks at patterns of transitivity that describe a character. Transitivity is a linguistic framework where grammar is encoded in the clause and it is one of the implicit and subtle linguistic features of a literary text. It also means accommodating in grammar a host of more abstract relations such as those that pertain between objects, circumstances and logical concepts.

The particular grammatical facility used for capturing experience in language is the system of transitivity. Transitivity here refers to the way meanings are encoded in the clause and to the way different types of processes are represented in language. Transitivity normally picks out three key components. The first is the process itself which is typically realized in grammar by the verb phrase. The second is the participants associated with the process typically realized by noun phrases. Less importantly, transitivity picks out the circumstances associated with the process and the third element is expressed by prepositional and adverb phrases.

The concept of textual medium is in tandem with the distinction between plot and discourse. It refers simply to the physical channel of communication through which a story is narrated. It is the core in the transmission of narrative experience.

Sociolinguistic code expresses through language the historical, cultural and linguistic setting that frames a narrative. It locates the narrative in time and place by drawing upon the forms of language that reflect this sociocultural context. Sociolinguistic code is a term referring to the pool of linguistic varieties that both derive from and shape the social and cultural backdrop to a text. It encompasses, amongst other things, the varieties of accent and dialect used in a narrative, whether they are ascribed to the narrator or to characters within the narrative, it is a key organizing resource for narrative. 
The first of the two characterization elements, actions, and events, describes how the development of character precipitates and intersects with the actions and events of a story. It accounts for the ways in which the narrative intermeshes with particular kinds of semantic process, notably those of 'doing', 'thinking' and 'saying', and for the ways in which these processes are attributed to characters and narrators. It approaches narrative within the umbrella concept of 'style as choice'.

The second category of narrative characterizations, point of view, explores the relationship between mode of narration and a character's or narrator's 'point of view'. Mode of narration specifies whether the narrative is relayed in the first person, the third person or even the second person, while point of view stipulates whether the events of story are viewed from the perspective of a particular character or from that of an omniscient narrator, or indeed from some mixture of the two. The way speech and thought processes are represented in narrative is also an important index of point of view, although this stylistic technique has a double function because it relates to actions and events also.

Textual structure accounts for the way individual narrative units are arranged and organised in a story. A stylistic study of textual structure may focus on large-scale elements of plot or, alternatively, on more localized features of story's organization; similarly, the particular analytic models used may address broad-based aspects of narrative coherence or they may examine narrower aspects of narrative cohesion in organization. A stylistic study of textual structure may focus on large-scale elements of plot or, alternatively, on more localized features of story's organization; similarly, the particular analytical models used may address broad-based aspects of narrative coherence or they may examine narrower aspects of narrative cohesion in organization. Coherence refers to the way a text makes sense to readers and writers through the relevance and accessibility of its configuration of concepts, ideas, and 
theories. On the other hand, cohesion refers to the grammatical and lexical relationship between different elements of a text which hold it together (Halliday and Hassan, 1976).

According to Halliday and Hassan (1976), a text is a semantic unit whose parts are linked together by explicit cohesive ties. This cohesive tie is a semantic and/or lexico-grammatic relation between an element in text and some other element that is crucial to interpretation of it. Even though within sentence ties occur. The cohesive ties across sentence boundaries are those, which allow sequences of sentences to be understood as text. Halliday and Hassan (1976) identify general categories of cohesive devices that signal coherence in texts.

Reference; as in personal pronouns, comparative constructions, and demonstratives. Ellipsis; again, a point in the flow of text is made sense of by making a mental connection to some adjacent text (called the co-text), but here what characterizes the point in the flow of text is the ellipsis of understood material. Substitution; whether nominal, verbal, or clausal; it involves replacement of one item by another. There is a relation in the wording rather than in the meaning. There are three types of substitution. Conjunctions; these are words or group of words that are used to connect words, phrases or clauses. According to (Halliday and Hassan, 1976), the conjunction is one of the four kinds of cohesive devices in texts, "expressing certain meanings which presuppose the presence of other components in the discourse," and the relationship expressed by the conjunctions is termed as conjunctive relations. Lexical Cohesion; this is achieved by the selection of vocabulary. Whether by reiteration or collocation.

The term intertextuality, the sixth narrative component, is reserved for the technique of 'allusion'. Narrative fiction, like all writing, does not exist in a social and 
historical vacuum, and it often echoes other texts and images either as 'implicit' intertextuality or as 'manifest' intertextuality. In a certain respect, the concept of intertextuality overlaps with the notion of sociolinguistic code in its application to narrative, although the former involves the importing of other, external texts while the latter refers more generally to the variety or varieties of language in and through which a narrative is developed.

\subsection{Data and Data Processing}

The main sources of the present study are the Glorious Qur'an along with six different interpretations that focus mainly on the narration nature and the stylistic miraculousness of the Qur'an:

- Aj-Jurjani's, I'jaz al-Qur'an (1079)

- Az-Zamakhshari's, Al-Kashshaf (1195)

- Mahmud al-Alusi, Rūh al-Ma'ānī fĩ Tafsīri-l-Qur'āni-l-'Aẓ̄im (1853)

- $\quad$ Said Okur I Nursî, Risale-i Nur (1950)

- Muhammad Rashid Rida, Tafsir al-Manar (1947)

- Ash-Sha'raawi's, Khawater Ash-shaarawi (1992)

The present study also deploys three different translations to the Qur' an as secondary resources, these specific translations are selected because they are of the most recent interpretations of the glorious script.:

- Towards Understanding the Ever-Glorious Qur'an (Muhammad Mahmoud Ghali, 2003)

- The Qur'an: a New Translation (Muhammad Abdel-Haleem, 2004)

- The Gracious Quran Complete: A Modern Phrased Interpretation in English (Ahmad Zaki Hammad, 2008) 


\subsection{Procedures of Data Analysis}

Data analysis is conducted by applying Simpson's Stylistic Narrative Model (2004). For deep and surface analysis, other studies such as Labov (1972), Short (1989, 1996), and Culpeper $(2001,2008)$ are applied.

Lakoff and Johnson (2003) explain that "Conceptual systems of cultures and religions are metaphorical in nature". In other words, "all the significant assertions of theology are expressed in language that is irreducibly metaphorical" (Avis, 1999: 90). Language that "is not assumed to be a representation of ideas" (Scott, 1988: 34) is not only an empire of signs, but also an empire of metaphors. In addition, "metaphors are iconic signs presenting meanings as well as representing meanings" (MacCormac, 1990: 192). Kövecses mentions (2002: 6) that metaphors typically use abstract concepts and assume that these concepts are physically concrete. Abstract concepts without metaphors are incomplete; furthermore, we complete our intellectual world through metaphor.

Not only the Qur'an but also the "whole of our universe is textual" (Barry, 2002: 35). In addition, texts are clues and they teach how to read the lives people live. "Texts, messages, and symbols never speak for themselves. They inform someone" (Krip-pendorff , 2004: 25).

According to Lakoff and Johnson (2003: 273), "we live our lives on the basis of inferences we derive via metaphor". They also say 'yes' to the question of "do you think the whole world is a metaphor for something?" (Skarmeta, 1987: 15-16). Each new metaphor shows a new dimension of realities in the world; therefore, each metaphor is a new discovery. To understand metaphors in our lives is to realise who we are and which society we live in. 


\section{Analysis and Discussion}

The researcher employs Paul Simpson's Model of Narrative Structure (2004).

\subsection{Prophet Ayyub's Story}

Prophet Ayyub's story is mentioned in the Holy Qur'an two times. As per Qur'anic scholars whose interpretations are adopted in this study, Ayyub, prior to his illness, was an extremely wealthy man. He possessed treasures of gold and silver, and he owned land, farms, fields, and cattle. He also had many children. Scholars add that the illness overtook him when he was seventy years old. The illness was so severe. Historians have written that not a single limb of Ayyub was free from disease except his tongue and his heart, which he used for the remembrance of Allah. He lost his children and his whole family except his wife who remained devoted to him.

Scholars have recorded different durations and the extent of the Prophet's illness. Some claimed his illness lasted three years, others claim seven years, and others claim eighteen years. Regardless of the exact number of years, Prophet Ayyub patiently bore his illness for a very long time. Never did Prophet Ayyub lament, grow angry, or reject the fate which Allah had decreed for him. Day and night, throughout the pain and difficult times, Prophet Ayyub would always praise Allah. That is why all Ayyub's prayers were accepted.

That is why Qur'an narrates the story of prophet Ayyub, peace be upon him, as an example in patience; Ayyub's verses are exposed to the afflictions that faced his life; his body, his money, and his son. The verses narrate the story of his patience, his turning into Allah, and his faithful dedicated prayers.

Hereinafter are the two different narratives narrating Prophet Ayyub's story. Although they both tell a story about the same person, Prophet Ayyub, they still 
differ in many aspects. They both come in a different position in the Qur'anic book, they both differ in the amount of what they say/not say, and they both differ in how they say it. This all result in different interpretations and explanations to the same story. These changes that took place are what the researcher believes to be a shift in the narrative, a Narrative Shift.

\begin{tabular}{|c|c|}
\hline \multicolumn{2}{|c|}{ Narrative (1) } \\
\hline Al-Anbiya (The Prophets) 83-84 & الأنبياء 83-84 \\
\hline \multicolumn{2}{|c|}{ 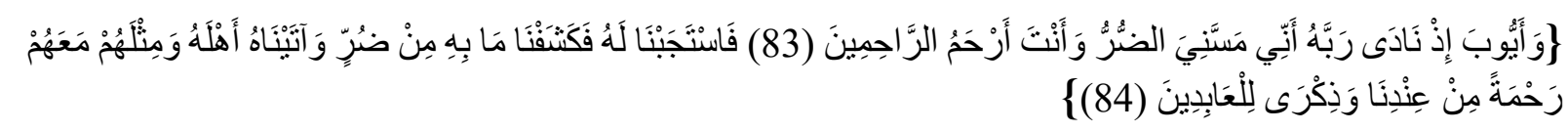 } \\
\hline \multicolumn{2}{|c|}{$\begin{array}{l}\text { And (remember) Ayub (Job), when he cried to his Lord: "Verily, distress has seized me, and } \\
\text { You are the Most Merciful of all those who show mercy (83) " So We answered his call, and } \\
\text { We removed the distress that was on him, and We restored his family to him (that he had lost), } \\
\text { and the like thereof along with them, as a mercy from Ourselves and a Reminder for all who } \\
\text { worship Us (84) }\end{array}$} \\
\hline
\end{tabular}

\begin{tabular}{|c|c|}
\hline \multicolumn{2}{|c|}{ Narrative (2) } \\
\hline Ṣād (Sad) 43-46 & ص 46-43 \\
\hline \multicolumn{2}{|c|}{ 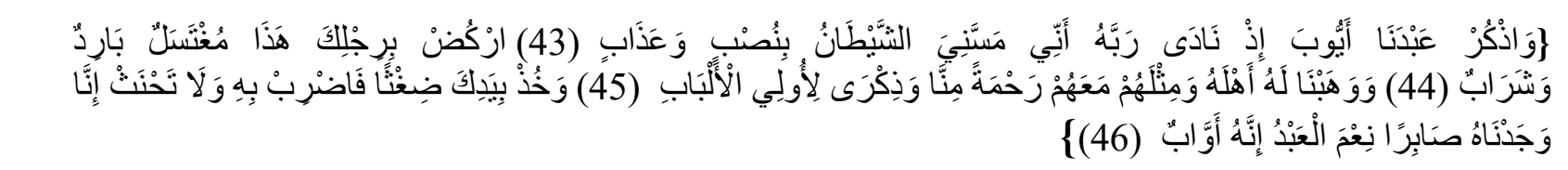 } \\
\hline $\begin{array}{l}\text { And remember } \\
\text { (Satan) has touch } \\
\text { (43) (Allah said } \\
\text { cool and a (refre } \\
\text { the like thereof, } \\
\text { in your hand a b } \\
\text { Truly! We foun } \\
\text { repentance (to U }\end{array}$ & $\begin{array}{l}\text { ord (saying): "Verily! Shaitan } \\
\text { orment (by losing my wealth)! } \\
\text { is a spring of water to wash in, } \\
\text { is family, and along with them } \\
\text { who understand (45) "And take } \\
\text { wife), and break not your oath. } \\
\text {, he was ever oft-returning in }\end{array}$ \\
\hline
\end{tabular}

\subsubsection{Textual medium}

This refers simply to the physical channel of communication through which a story is narrated. According to Simpson's analysis of style, a narrative may be encoded in 
a variety of textual media. As argued by Bradford and Simpson (1997, 2004), the following hence forms what Propp's model suggests about what is core in defining textual medium.

Simpson argues that textual medium can be triggered through many textual media. In the present study, only relevant media are adopted. They are flashbacks, symbolism, parallelism, and imagery.

Flashback is a literary device wherein the author depicts the occurrence of specific events to the reader, which have taken place before the present time of narration, or events that have happened before the events that are currently unfolding in the story. Both Narrative (1) and Narrative (2) are flashbacks inside their chapters to past events. This is remarked with the past tense usage in both of them. Also, it is clear in Narrative (1) by the use of "and a Reminder/وَذِكْرَى", and in Narrative (2) use of

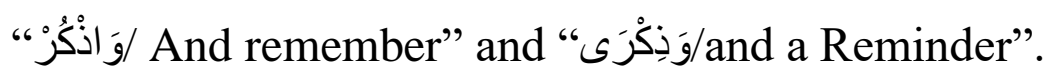

Symbolism exists whenever something is meant to represent something else. It is a figure of speech used to create a certain mood or emotion. In Narrative (1) the “distress" “"الضُّرُ is used to symbolizes Ayyub's sickness, however, the word here is attached to the verb "مَسَّنَّيَّ/seized" to describe the sickness effect too and how harmful it is. This symbolism that treated " مَسَّ " as a human who is able to

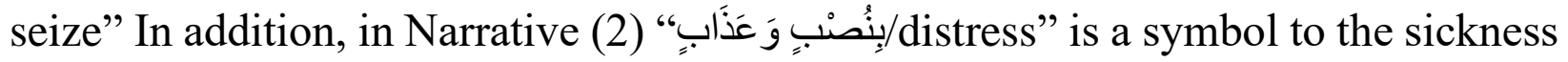
again; but here " "مَ/seize" is used with the Satan for readers to feel the meaning gaps and the distress and the Satan. However, for Asha'arawi the distress in here is not the sickness as in Narrative (1), it is rather the satan's disquietude to Ayyub weakening his will and patience.

Parallelism is a textual media balancing two or similar words, phrases or clauses, and repeating similar or identical patterns in adjacent phrases, clauses or sentences. 
This is to improve readability. These two narratives are a perfect example of parallelism, their grammatical structure, their phonological similarity and synonymy, and their adjacent sentences. They both can be seen as paralleled pattern explaining and redefining one another. Short (1996) offers an interesting explanation about parallel structures. He argues that parallelism has the power not just to foreground parts of a text for us but also to make us look for parallel or contrastive meaning links between these parallel parts (p. 15). This is meant so that readers would recall each narrative when reading the other, filling the informative gaps, and getting that feeling of coherency between all of the Qura'nic chapters and their topics.

Imagery may be a metaphor, a simile, or a figure of speech, a concrete verbal reference, a recurrent motif, or a psychological event in the readers' mind. (The Nairobi Journal of Literature, 2006). The linguistic feature with imagery is the

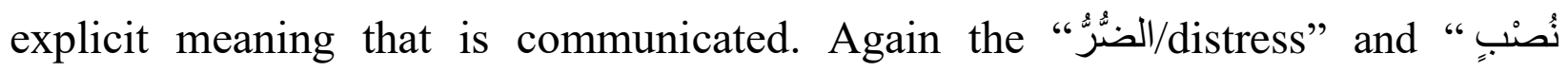
/وَ عَذَابٍٍ distress" an imagery of the sickness in Narrative (1) and as a symbol to satan's disquietude in Narrative (2).

\subsubsection{Sociolinguistic code}

Sociolinguistic code expresses through language the historical, cultural, and linguistic setting which frames a narrative. It locates the narrative in time and place by drawing upon the forms of language which reflect this sociocultural context. Sociolinguistic code encompasses amongst other things the varieties of accent and dialect used in a narrative, although the concept also extends to the social and institutional registers of discourse deployed in a story. Sociolinguistic code is a term referring to the pool of linguistic varieties that both derive from and shape the social 
and cultural backdrop to a text. Sociolinguistic code is a key organizing resource not just for narrative but also for all types of literary discourse (Simpson, 2004).

For the present study, only literary code-switching is to be found in the Qur'anic narrative, a sophisticated technique which signals movement between different spheres of reference and has important consequences for a range of thematic intentions. For the above narrative shift, a switch between telling the story without reference to any details, and detailing the story is clearly found. Narrative (1) does not give much details, it rather uses uninformative images like " "الضشرُهُ/distress". While

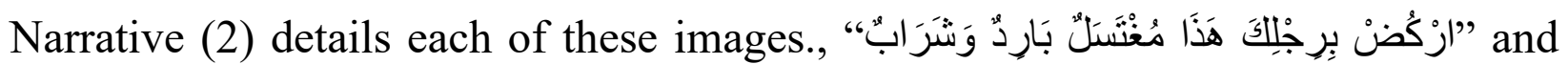

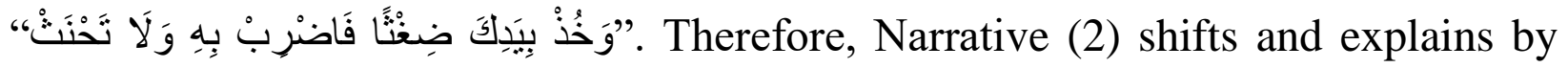

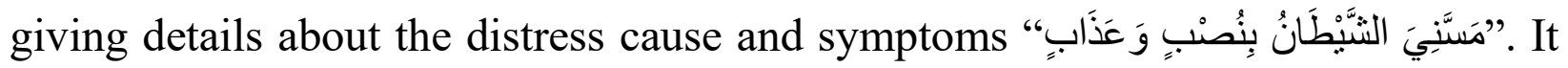

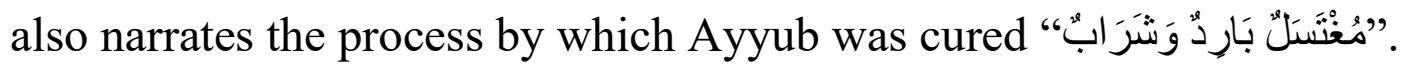

\subsubsection{Characterization 1: actions and events}

In a brief account of transitivity, five types of processes are identified in which actors or agents do things that affect other participants. Sensors perceive phenomena, and entities are assigned attributes. In addition, processes are realized by verbs, entities by nouns and attributes by adjectives, for instance.

Through these verses, certain linguistic devices are employed to reinforce the differences in the representation of devil verses Allah and His prophets. They also play the role of thump in determining the power relations and how power is so much related to the central theme of faith and submission in the verses. In addition, these devices help readers in their journey to believe since they elicit people'ssubmission and loyalty to Allah. 


\subsubsection{Material Processes}

\begin{tabular}{|c|c|c|c|c|}
\hline & Process & Actor & Goal & \\
\hline 1 & 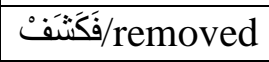 & Lا/We (Allah) & Invisible/ the distress & Narrative (1) \\
\hline 2 & |أَتَيْنَ/restored & LاWe (Allah) & Invisible/ Ayyub family & Narrative (1) \\
\hline 3 & |رارَضْن & $\begin{array}{l}\text { Invisible Pronoun "You" } \\
\text { (Ayyub) }\end{array}$ & Invisible/the ground & Narrative (2) \\
\hline 4 & 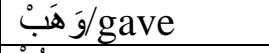 & L/We (Allah) & Invisible/ Ayyub family & Narrative (2) \\
\hline 5 & ذُ & $\begin{array}{l}\text { Invisible Pronoun "You" } \\
\text { (Ayyub) }\end{array}$ & & Narrative (2) \\
\hline 6 & |اضْرِبْ & $\begin{array}{l}\text { Invisible Pronoun "You" } \\
\text { (Ayyub) }\end{array}$ & Invisible/Ayyub's wife & Narrative (2) \\
\hline 7 & 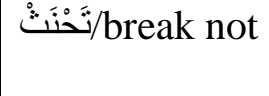 & $\begin{array}{l}\text { Invisible Pronoun "You" } \\
\text { (Ayyub) }\end{array}$ & Invisible/oath & Narrative (2) \\
\hline
\end{tabular}

Processes 1, 2, and 4 are Allah's. And while 3 ,5, 6, and 6 are Ayyub's, they are all still with Allah's orders since they are all imperative forms from Allah to Ayyub. Ayyub in Narrative (1) is not part of the process, as opposed to Narrative (2) in which he is the actor. A very noticeable distinction here is the use of the imperative form, giving the material process a different sense. Ayyub is the actor; however, he is the actor to an already given order by Allah. Actors are always identified as being the controllers of the process. In that sense, in Narrative (2), Ayyub is the strong doer of the actions, however, his powers are because of Allah's guidance and commands.

While in Narrative (1), Allah is the controller to all Ayyub's universe including the distress, the family, and even the "thereof" his family. This again stresses the obedience and submission topics of Narrative (2) as complementary themes to the faith and oneness topics of Narrative (1). All the processes are crammed with power connotations allotted to their doers (actors). The meaning embedded in the processes reveal the powerful VERSES powerless relationship and role in the narrative. Allah is the powerful in Narrative (1), and Ayyub is the powerful with his submission to Allah in Narrative (2). This is why the only process with Allah as the actor in 
Narrative (2) is for the process "وََ/we gave", proving that Allah's gits and offerings are for those who choose to obey.

\subsubsection{Verbal Processes}

\begin{tabular}{|c|c|c|c|c|}
\hline & Process & Sayer & Addressee & \\
\hline 1 & انَادَى/cried & Ayyub/أَيْوبَ & & Narrative (1) \\
\hline 2 & اذُّكُ/remember & Allah & $\begin{array}{l}\text { Invisible Pronoun "You" } \\
\text { (Prophet Muhammad) }\end{array}$ & Narrative (2) \\
\hline 3 & & $\begin{array}{l}\text { Invisible } \\
\text { (Ayyub) }\end{array}$ & رَبَّهُ & Narrative (2) \\
\hline
\end{tabular}

These processes support the researcher's claim about power relations in these two narratives. On one hand, Narrative (1) Ayyub is calling for the help of the actor of the previous process, Allah. He is crying for Allah's help and support to save him. On the other hand, Narrative (2) has the same process of "نَادَى/cried"; however, the process of “اذاذكُرْ//remember” is added to stress the importance of knowing Ayyub's story as believers. Allah is stressing on prophet Muhammad PBUH to transfer Ayyub's story as a lesson for all believers to draw.

\subsubsection{Mental Processes}

\begin{tabular}{|c|c|c|c|c|}
\hline & Process & Senser & Phenomenon & \\
\hline 1 & اسنتَجَبْ & LاWe (Allah) & 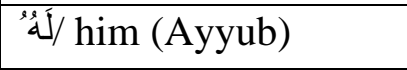 & Narrative (1) \\
\hline 2 & اذذكُرْ//remember & $\begin{array}{l}\text { Invisible Pronoun "You" } \\
\text { (Prophet Muhammad) }\end{array}$ & 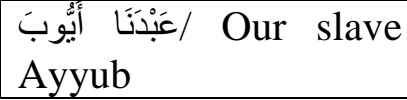 & (2) \\
\hline
\end{tabular}

Some of the mental processes here are mental in sense. For the process اذْكُرْ $/$ /remember for example it can be seen as both, verbal as mentioned earlier; and mental in the sense that Allah is asking prophet Muhammad to think and draw of Ayyub's story. He want Muhammad to know and remember this story for a full awareness of what honest believers do. All these processes reinforce the power 
relations revealed by the previous two processes. However, they emphasise them from a holly view, the view of believers who trust and draw. This reveals the positive

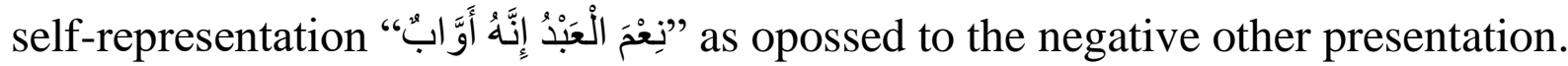

\subsubsection{Relational Processes}

\begin{tabular}{|c|c|c|c|c|}
\hline & Process & Carrier & Attribute & \\
\hline 1 & اورَجَذْ / found & \&/him (Ayyub) & / لَِعْمَ الَْعَبُْ excellent (a) slave & Narrative (2) \\
\hline 2 & إِنَّ/ was & s/he (Ayyub) & $\begin{array}{l}\text { أؤَ } \text { ever oft-returning in } \\
\text { repentance }\end{array}$ & ve (2) \\
\hline
\end{tabular}

In addition, the process of "وَجَدْ found" is mental since it speaks of Ayyub's being as an excellent servant. In the same sense, the process “/ إَِّّ / was” is again describing Ayyub’s being as “'أََّّابُ “". This all stresses how Allah see his believers and followers and they are positively described and portrayed in Narrative (1) as opposed to Narrative (1) that is concerned with faith only; no duties are described nor an image of a true believer drawed.

Considering all the above-mentioned processes, it is very easily to notice how Allah identifies Himself as a controller and His followers as believers. Again, this raises the interpretations of positive self-presentation as mentioned earlier in the mental process and supports the researcher's claim about their usage.

\subsubsection{Characterization 2: points of view}

Traditionally it is defined as the perspective or vantage point from which the narrator of prose fiction perceives the events, actions and happenings in the story (Simpson, 2004). The omniscient narrator often knows more than what the characters know about themselves and can decide to enter or restrain from their feelings and thinking processes at any time. (Simpson, 2004; Arp and Johnson, 
2006). And since the first person knows his owns along with the storyline, the Qur' an is viewed as having a mix of both based on the transitivity analysis above.

This view of Qur'an is clear in the way speech and thought processes are represented in the above verses. Allah is the narrator of the verses; he is the omniscient narrator of Ayyub's thoughts, and also the narrator of all the events and actions. In addition, $\mathrm{He}$ is the first-person narrator of His own actions and thoughts. Allah narrates Himself as the actor in the material processes, and even when He is narrating Ayyub as the actor, he is the actor of only imperative forms.

\subsubsection{Textual structure}

The narrative shift under analysis has a clear textual narrative structure due to the presence of so many textual elements that adds to its cohesiveness. (See sec. 3.1.2)

\begin{tabular}{|c|c|}
\hline Narrative (1) & Narrative (2) \\
\hline أيُّوبَ & أأيُوبَ \\
\hline 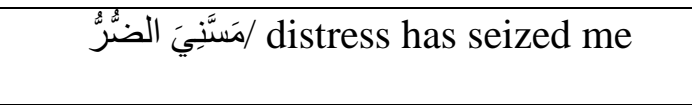 & 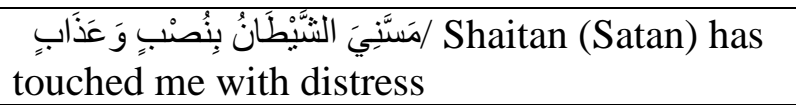 \\
\hline 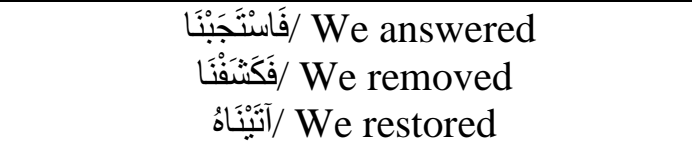 & اوَهَ هَبْنَا \\
\hline 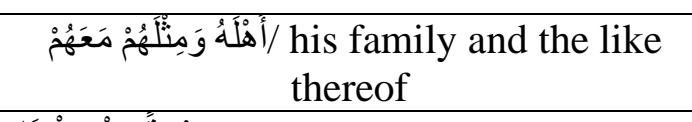 & 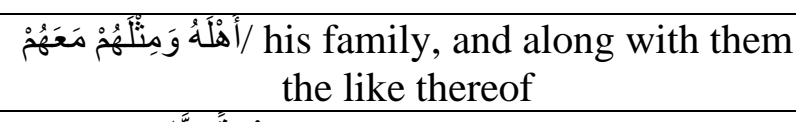 \\
\hline ارَحْمَة مِنْ عِنْدِنَا & ارَحْمَة هِنَّا \\
\hline $\begin{array}{l}\text { / ذَذكرَى لِلْعَاِِدِينَ a Reminder for all who } \\
\text { worship Us. }\end{array}$ & 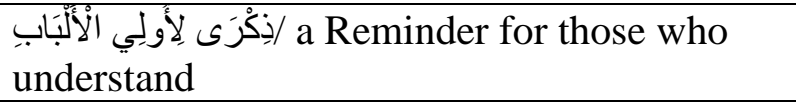 \\
\hline
\end{tabular}


In spite of having shifted in the narrative, the use of reiterations and collocations in the verses made them a one coherent unit. Embedding a spontaneous mental connection especially when the events' sequencing shifted from Narrative (1) مَسَّنِيَ)

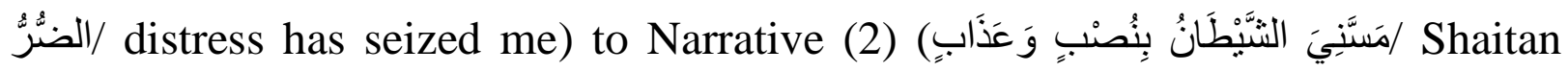
(Satan) has touched me with distress).

\subsubsection{Intertextuality}

The term intertextuality, the sixth narrative component, is reserved for the technique of "allusion". In a certain respect, the concept of intertextuality overlaps with the notion of sociolinguistic code in its application to narrative, although the former involves the importing of other, external texts while the latter refers more generally to the variety or varieties of language in and through which a narrative is developed (Simpson, 2004). It supports the concept that the meaning of a text does not reside in the text, but is produced by the reader in relation not only to the text in question, but also the complex network of texts invoked in the reading process. Intertextuality seems such a useful term because it foregrounds notions of relationality, interconnectedness, and interdependence.

The narrative shift under analysis reveals how the same story is being imported and reproduced more than one time, allowing the reader to relate different parts of the same story along the process of reading the Qur'an.

This is clear in importing and reproducing the concept of the distress in Narrative

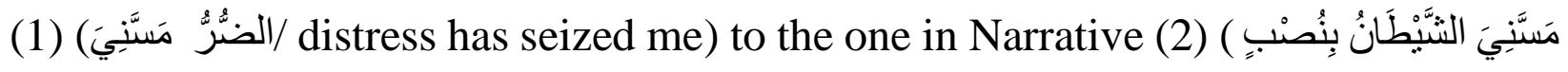
كوَ عَذَابِ Shaitan (Satan) has touched me with distress). And again, in reproducing the

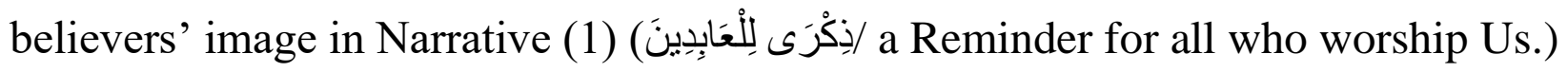

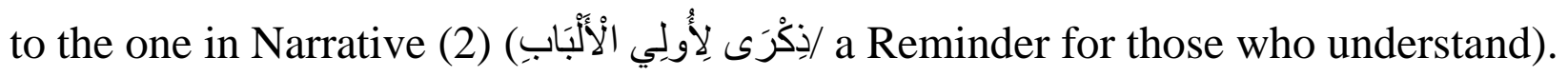




\section{Conclusion}

The present study analyzed the Narrative Shift in Prophet Ayyub's Qur'anic story as a representative sample of the Narrative Shift in the Qur'an's narrative discourse. This chapter aims to summarize the findings of the analysis to find out to what extent the analysis findings give answers to the research questions raised in the introduction.

\subsection{Narrative Shift Form and Function}

- What are the Narrative Shifts, their linguistic characteristics, and their function in the Qur'an?

The main question raised in the present study is "What are the Narrative Shifts, their linguistic characteristics, and their function in the Qur'an?" As already discussed, and explained under the macro analysis, micro analysis, and the analysis discussion sections. Narrative Shift is a shift that occurs in the narration process on one or more than one level as a remarkable feat of restructuring and reconstructing the narrative. It allows closing all of the narrative gaps on almost every level; moral, psychological and metaphysical.

\subsection{Lexico-Grammatic Devices of Rhetoric and Persuasive}

- How are the Qur'anic rhetoric and persuasive devices expressed on the lexico-grammatical level?

Structurally, Arabic is identified to be a figurative language. It employs all the possible lexico-grammatic devices to affect readers/listeners perceptions to the many themes discussed under its biggest umbrella; the Islamic Religious Belief. So, to distribute faith, oneness, advocacy, etc. this has to be firmed figuratively through the only discourse to which all Muslims would avail themselves. 


\subsection{Narrative Shift and The Qur'anic Discourse}

- To what extent have the Narrative Shifts influenced the Qur'anic discourse's intertextuality?

Without a Narrative Shift as a Qur'anic discoursal feature, many of the intertextual elements would have been missing from the Qur'an. Shifting a narrative to its appropriate contextual purpose is what has been discussed in the present study for readers to perceive why a story is narrated through many different yet correlated narrations appointing different yet connected plots. 


\section{References}

Abdul-Raof, H. (2003). Exploring the Qur'an. Dundee: Al-Maktoum Institute Academic Press.

Adichie, N. (2013). Americanah. Nairobi: Kwani Trust.

Afsar, Ayaz. (2009) "A Comparative Study of the Art of Jonah/Yūnus Narrative in the Bible and the Qur'ān." Islamic Studies 48/3: 319-339.

Al-Arna'ut, A. (2003). A compilation of the Abridged Tafsir Ibn Kathir: (abridged). Riyadh, RY: Darussalam.

Al Fayad, M.G. (1995). Parables in The Glorious Qur'an. Riyadh, RY: International Islamic Publishing House.

Al Shaarawy, M. 1997. Tafsir al-Sharawi. Cairo: Akhbar El Yom Press.

Babazadeh AA. 2003. teaching practices and propaganda, printing, Danesh \& Adab publishing, Qom, Iran

Bradford, R. (1997). Stylistics. London and New York: Routledge.

Bridgeman, T. (2007). Time and space. In D. Herman (Ed.), The Cambridge Companion to Narrative (pp. 52-65). chapter, Cambridge: Cambridge University Press.

Browne, H. (2007). World history (2) 1900 - 2005. London: Cambridge University Press.

Cooper, B. (2010). Resurgent Spirits, Catholic, Echoes of Igbo and Petals of Purple: The Syncretised World of Chimamanda Ngozi Adichie's Purple Hibiscus in New Novels in African Literature Today. Ernest N. Emenyonu (ed).Rochester James Currey.

Cowie, A. P. (ed) (1989). Oxford Advanced Learners Dictionary of Current English 4th ed. Oxford: OUP

Crystal, D. \& Davy. (1969). Investigating English Style. London: Longman.

Deilami A, Azerbaijani M. 2002. Islamic ethics, eleventh edition, Islamic publications. Qom, Iran 
Emmott, C. (1997) Narrative Comprehension: A discourse perspective. Oxford: OUP

Enkivist, N. et al (1978). On Defining Style: In Linguistics and Style. Oxford: OUP.

Fadlallah MH. 2005. steps in teaching, translation by Ahmed Beheshti, First Edition, published by Amir Kabir, Tehran, Iran

Fowler, R. (1996). Linguistic Criticism, 2nd edition. Cambridge: Cambridge University Press.

Genette, G. (1983). Narrative Discourse: An Essay in Method, translated by Jane E. Lewin. New York: Cornell University Press.

Halliday, M. A. (1978). Language as Social Semiotic: The Social Interpretation of Language and Meaning. London: Edward Arnold.

Heather, H. (2005). Coming of Age: Chimamanda Ngozi Adichie and the Voice of the Third Generation. English in Africa, 32 (1), 73.

Hoover, D. (1999). Language and Style in the Inheritors. LanHam, MD: UP of America.

Ibn Abi al-Hadid, A-H. 2007. Hijri Ghamari, Nahj-Albelagha description, second edition, Darahya' Al Altras Al-Arabi. Beirut,lobnan

Jahn, M. (2007). Focalization. In D. Herman (Ed.), The Cambridge Companion to Narrative (pp. 94-108). chapter, Cambridge: Cambridge University Press.

Javadi A. 1996. Shia Encyclopedia, First Edition, Shahid Mohebi publication. Tehran,Iran

Kadenge, E .(1982). Deviation and Foregrounding in chosen Swahili Literary texts. Unpublished M. A. Thesis. University of Nairobi.

Kermode, F. (1979). The Genesis of Secrecy: On the Interpretation of Narrative. London: Harvard University Press.

Kiguru, D. (2012). Violence in Childhood Narratives: Chimamanda Adichie's Purple Hibiscus and Half of a Yellow Sun. Unpublished M.A. Thesis. University of Nairobi. 
Klein MY. 1986. Kafi principles, second edition, Elmie Islamie Press. Tehran,Iran

Le Carré, J. (1986) A Perfect Spy. London: Hodder and Stoughton

Leech, G. \& Short, M. (2007). Style in fiction. Harlow: Pearson Education Limited.

Leech, G. (2008). Language in literature. Harlow: Pearson Education Limited.

Marefat MH. 2001. Hijri Ghamari, Talkhis Al-Tamhid, fourth edition, Islamic Publications Bureau. Qom,Iran

Marefat MH. 2005 a criticism on doubts about Quran, translated by Hassan Hakim Bashi, first edition, Tamhid cultural institute. Qom,Iran

Margolin, U. (2007). Character. In D. Herman (Ed.), The Cambridge Companion to Narrative (pp. 66-79). chapter, Cambridge: Cambridge University Press.

Matthews, P. H. (2007). The concise Oxford dictionary of linguistics. Oxford: Oxford University Press.

McIntyre, D. (2006) Point of View in Plays. Amsterdam and Philadelphia: John Benjamins Publishing Company

McIntyre, D. and Busse, B. (eds) (2010) Language and Style. Basingstoke: Palgrave Macmillan

Mikov, G. (2003). Linguistic stylistics. Nitra: Filozofick Faculta Univerzita Kontantna Filozofa.

Mills, S. (1995). Feminist stylistics. London and New York: Routledge.

Moein M.1994. Moein dictionary, Amir Kabir Publications,Tehran,Iran

MohieAldin D.1987. Al-Bayanfi al-A'arab,second,edition,darAlktb, Beirut,lobnan

Motahari M.1982. HosseinEpic, Tenth edition, Sadra., Qom,Iran

Motavalli K. 2005. public opinion and persuasion techniques, printing, Behjat Press, Tehran, Iran 
Moradi H. 2010. of persuasion and communication, second edition, Saghi publication. Tehran,Iran

Ofeimum, O. (1988). Kole Omotoso, Ogunbiyi, Y. Ed. Perspectives on Nigerian literature: 1700 to the present Vol 2. Lagos: Guardian Books Nigeria Ltd. 185 - 194.

Olateju, M. (2004). Discourse analysis. Ife: Obafemi Awolowo University Press.

Omotoso, K. (1988). Just before dawn. Ibadan: Spectrum Books.

Pratkanys A, Aronson E. 2005. Propaganda Age, translated by Kavous Sayed Imam Sadegh Abbasi, fourth edition, Soroush Press. Tehran,Iran

Pyrhönen, H. (2007). Genre. In D. Herman (Ed.), The Cambridge Companion to Narrative (pp. 109-124). chapter, Cambridge: Cambridge University Press.

Qera'aty M.1998. Quran and advertising, Cultural Center of the Qur'an lessons, Tehran, Iran

Qutb, S. 1960. Fi Zilal al-Qur'an, Translated by Adil Salahi (2015). Leicestershire: Kube Publishing Ltd

Sarookhani B. 2004. Persuasion as the Aim of communication, Social Science Quarterly, No. 23, Page 115, Tehran University,Iran

Semino, E. and Short, M. (2004) Corpus Stylistics: Speech Writing and Thought Presentation in a Corpus of English Writing. London: Routledge

Semino, E., Short, M. and Wynne, M. (1999) Hypothetical Words and Thoughts in Contemporary British Narratives. Narrative, 7 (3), 307-333

Sharif R. 1985. Hijri Ghamari, Talkhis Albayan fi Mojazat Al-Quran, Alamol Ketab, Beirut,lobnan

Shaker MK. 2003. Principles and methods of interpretation, first edition, the center of global Islamic sciences. Qom,Iran

Short, M. (1996) Exploring the Language of Poems, Plays and Prose. London and New York: Longman 
Simpson, P. (2004). Stylistics. London and New York: Routledge

Syooty J. 2002. Alatqan fi al Oloom Alghoran, translated by Mehdi Haeri Ghazvini, Fifth Edition, Amir Kabir Publications Tehran,Iran

Simpson, P. (1993) Language, Ideology and Point of View. London and New York: Routledge

Stockwell, P. (2002) Cognitive Poetics: An Introduction. London: Routledge

Thomas, B. (2007). Dialogue. In D. Herman (Ed.), The Cambridge Companion to Narrative (pp. 80-93). chapter, Cambridge: Cambridge University Press

Thompson, G. (2004) Introducing Functional Grammar (2nd ed.). London: Arnold

Troudi, K. (2011) Qur'ānic Hermeneutics with Reference to Narratives: A Study in Classical Exegetical Traditions. University of Exeter.

Ufot, B. (2006). An introduction to practical stylistics. Lagos: Solar Flares Communications.

Uspensky, B. (1973) A Poetics of Composition, trans V. Zavarin and S.Wittig, Berkely: University of California Press

Vasei SAR, Dayyani MS. 2006. Introduction to the A'emah teaching methods, first edition, Institute of Islamic Sciences and Culture, Qom.iran amani MH. 2006, Orientalists and the QuranBoostane Ketab. , Qom,Iran

Wales, K. (2011). A dictionary of stylistics. Harlow: Pearson Longman.

Werth, P. (1999) Text worlds: Representing conceptual space in discourse. Harlow and New York: Pearson Education Limited

Widdowson, H. G. (1975). Stylistics and the teaching of literature London: Longman. 